\title{
Panoramic Lutheranism and apocalyptic ambivalence: an appreciative critique of N. T. Wright's Paul and the Faithfulness of God
}

\section{Douglas A. Campbell}

The Divinity School, Duke University, Durham, NC 27708, USA

dcampbell@div.duke.edu

\begin{abstract}
The basic agenda and resulting architecture of N. T. Wright's reconstruction of Paul's theology in Paul and the Faithfulness of God are a dramatic and brilliant break with most previous analyses and an important step forward. But closer analysis suggests that his project also contains some serious problems. First, it is not well executed: there are basic problems of method and exegesis with Wright's manner of reading Paul's texts. Second, Lutheranism and various modern dichotomies have not been purged sufficiently thoroughly from Wright's reconstruction of Paul's thought, resulting in tensions of truly tectonic proportions. One is left with the impression of a magnificent venture foundering in its haste - haste perhaps extending back to the venture's original design, when certain contradictory tendencies needed to be confronted and solved, but were not.
\end{abstract}

Keywords: apocalyptic, covenant, Lutheran reading, Marcionism, Paul, N. T. Wright

N. T. (Tom) Wright's Paul and the Faithfulness of God (hereafter PFG) is a large work so even a review of this length will have to be regrettably selective. ${ }^{1}$ I will focus in what follows primarily on a characteristic interest of both Wright's and mine, namely, the theological dimension within the interpretation of Paul. ${ }^{2}$

Wright within the modern interpretation of Paul's theology

I recently taught an advanced survey course at Duke Divinity School on modern theological accounts of Paul and related scholarly trends,

${ }^{1}$ N. T. Wright, Paul and the Faithfulness of God (hereafter PFG), 2 vols., vol. 4 of Christian Origins and the Question of God (Minneapolis: Fortress, 2013).

2 Paul's interpretation should by no means be reduced to this dimension or 'level' within his reconstruction, but nor should it be left out; see my account of its exact location and interpretative function in relation to other interpretative concerns in ch. 7 of The Deliverance of God: An Apocalyptic Rereading of Justification in Paul (Grand Rapids, MI: Eerdmans, 2009), pp. 221-46. 
and - sadly - a general impression formed that this entire interpretative trajectory is somewhat impoverished. Three recurring problems emerged that can help to set the scene for Wright's important recent statement in PFG.

First, the reconstructions of Paul's thought offered in the modern period have generally been dominated by one particular model, despite its manifest flaws - a reconstruction Krister Stendahl famously dubbed 'the Lutheran reading' . ${ }^{3}$ This model departs from a particular reading, unsupported by any explicit warrant, of a single Pauline sub-section within a single Pauline letter, ${ }^{4}$ yet it exercises a dominance over Pauline theology out of all proportion to its actual presence within his work, not to mention within the broader theological conversations in the church. (It is also arguably a tendentious account of Lutheranism.)

Second, the conversation has been strangely constricted by a pervasive thought-act or being-act dichotomy. ${ }^{5}$ The analysis of Paul's thought has generally taken place in splendid isolation from the analysis of his (other) acts and activities, that is, his 'practical' missionary work that established and maintained congregations. ${ }^{6}$ Paul's practical activities were a theological text (and vice versa), and so they must be in play within any account of his theology. ${ }^{7}$

${ }^{3}$ See 'The Apostle Paul and the Introspective Conscience of the West', Harvard Theological Review 56 (1963), pp. 199-215. The tenacity of this model is arguably a classic instance of resistance by a 'paradigm' to revision; see Thomas S. Kuhn, The Structure of Scientific Revolutions, 3rd edn (Chicago and London: University of Chicago Press, 1996 [1962]).

${ }^{4}$ It assumes that Rom 1:18-3:20 is a praeparatio evangelica for the proclamation of the gospel, which is assumed to begin in 3:21, although there is no textual warrant either in Romans or elsewhere in the Pauline corpus that Paul operated with a praeparatio, or, if he did, that he operated with this one. See, by way of contrast, 1 Cor 2:1-5. I wonder if this is not the biggest interpretative assumption ever made within the western theological tradition.

${ }^{5}$ See Colin E. Gunton, Enlightenment and Alienation: An Essay toward a Trinitarian Theology (Eugene, OR: Cascade, 2006 [1985]); and Act and Being: Towards a Theology of the Divine Attributes (London: SCM, 2002). It is worth noting here in passing that the consequences for ethics are also very significant, so that e.g. Stanley Hauerwas tirelessly refuses to accept this distinction, along with its destructive consequences.

${ }^{6}$ A recent attempt to avoid this difficulty, prefacing a detailed account of Paul's thought with a detailed account of his life, ran into the further problem that accounts of Paul's activity, framed by his biography, are generally deeply flawed: see Udo Schnelle, Apostle Paul: His Life and Theology, trans. M. Eugene Boring (Grand Rapids, MI: Baker, 2005 [2003]). The methodological and biographical problems are explicated by my Framing Paul: An Epistolary Biography (Grand Rapids, MI: Eerdmans, 2014), pp. 1-36.

7 The seminal conversation partner here - as Wright is well aware - is Wayne Meeks; see his The First Urban Christians: The Social World of the Apostle Paul (New Haven: Yale University Press, 1983). Wright responds to this challenge principally through a vigorous 
Third, the conversation with actual theologians has generally been muted if not absent. It is as if NT scholars expect a mature analysis of theological questions to spring fully formed and self-evident from Paul's text, when long training in these questions is necessary even to recognise the issues in play, along with the culture-bound assumptions that might be distorting their handling by the modern western reader. ${ }^{8}$

Wright's reading of Paul in PFG - the culmination of many decades reflecting and publishing on the apostle - promises, by way of contrast, to break through these debilitating strictures. He is well aware of the Lutheran reading and of its post-Sanders conundrums, and is widely known as one of its most important revisionists. He eschews a merely conceptual account of Paul's thought, embedding it in a worldview analysis that stretches across to include what other scholars might view as merely practical activity. And he frequently claims to be interested - contra much modernity - in theology, and not to mention, in God. So, for example, his long account concludes by interacting with Walter Benjamin (PFG, pp. 1473-84, 1511-12). Hence the basic agenda and resulting architecture of Wright's reconstruction of Paul's theology are a dramatic and brilliant break with most previous analyses and an important step forward - a significant set of achievements that ought to be fully appreciated. But closer analysis suggests that his project also contains some serious problems.

First, it is not well executed. I will articulate my main concerns in more detail shortly, so suffice it to say here that there are basic problems of method and exegesis with Wright's manner of reading Paul's texts, while his engagements with other scholarly interlocutors frequently lapse into mere polemic. $^{9}$

deployment of worldviews; however, this arguably short-changes the conversation with sociology more broadly, since sociology is much more than worldview analysis.

8 In this relation a brief conversation with some of T. F. Torrance's work will prove salutary: see his Space, Time, and Incarnation (Oxford: OUP, 1969); and Space, Time, and Resurrection (Edinburgh: Handsel Press, 1976); not to mention an exchange with Alasdair MacIntyre (see esp. MacIntyre's Whose Justice? Which Rationality? (Notre Dame, IN: University of Notre Dame Press, 1988)). That is to say, assumptions concerning space, time, causality, rationality and justice need to be identified and scrutinised, since they are often highly culture-bound and traditioned.

9 I mean by this that their positions are often oversimplified and slanted to the point of unrecognisability - a strategy that then allows him to dismiss them with little difficulty. This straw-man technique produces a constantly frustrating read for other scholars of Paul. (Wright effectively trades on a level of ignorance in relation to the primary and the secondary literature. So I expect the bifurcation in his reception currently apparent between his more general, popular readership, and the scholarly community, to deepen as a result of this aspect of his project - a deeply regrettable trend.) 
But my main concern here is, second, that the basic account of Paul's theological thought Wright offers his readers is still unresolved. Lutheranism and various modern dichotomies have not been purged sufficiently thoroughly from his reconstruction, resulting in tensions of truly tectonic proportions. I hasten to add that these difficulties have usually been acknowledged, and even engaged with, but they have not been dealt with properly. And the result of this is a sense of disappointment. One is left with the impression of a magnificent venture foundering in its haste - haste perhaps extending back to the venture's original design, when certain contradictory tendencies needed to be confronted and, however painfully, solved, but were not.

Much of this tension results from the fact that PFG pursues two quite distinguishable agendas when reconstructing Paul's theology. ${ }^{10}$ What we might call a soteriological agenda programmatically resists its Marcionite construal, ${ }^{11}$ while a revelational agenda resists adoptionist and gnostic elements in reconstructing the apostle's thought. ${ }^{12}$ But the soteriological, anti-Marcionite agenda dominates the project, ${ }^{13}$ so I will focus on it here, scrutinising its internal coherence and its implicit occlusions - the first source of tension - before returning at the end of my review to consider quickly how these two fundamental agendas fit together, espying then a second key fault-line.

\section{The anti-Marcionite agenda}

In most of PFG Wright argues in familiar terms: that to understand soteriology in Paul, as indeed to understand anything else he says, one must grasp the story the apostle presupposes that is grounded in the Jewish scriptures of his

10 This is most apparent in the three long chapters composing part 3 of PFG that are the self-declared heart of the broader, two-volume project (pp. 609-1265).

11 I would want to qualify this immediately by stating that PFG resists both Marcionite and putatively Marcionite readings.

12 Wright means by 'Gnosticism', not unfairly, any dualism that emphasises too strongly a soul separable from the body and a consequent disembodied heaven as against a fully realised new cosmos. Wright equally resists an overly 'Platonic' reading of parts of Paul in these terms. This agenda is pursued most programmatically elsewhere in his The Resurrection of the Son of God.

13 The soteriological agenda dominates parts 1, 2 and 4, and the majority of part 3 . In part 3, soteriology makes its appearance in $\S 7$ of ch. 9, on p. 737, continuing through to the end of ch. 10 on p. 1042 . It is then resumed in ch. 11, p. 1128, with the discussion of unbelieving Israel, continuing through p. 1258 - a total of 435 pages within a part numbering 646 pages altogether (i.e. $68 \%$ or just over two-thirds of the material). Revelational discussions dominate the other sub-sections in chs. 9 and 11 , and tend to be muted elsewhere within the project. 
day. The story moves from a plight to a solution, although Wright detects a more complex, extended narrative here than most.

The story begins prior to creation with Wisdom, who sports with God, and through whom creation duly takes place. But creation is fractured by the fall of Adam and Eve, as recounted in Genesis 3. Almost immediately then we have to speak of a plight. Wright goes on to emphasise strongly the continuation of this biblical story to and through the call of Abraham. God promises to save humanity from its post-Adamic plight, and calls or elects Israel, descended from Abraham and Sarah, to do so; these moments constitute the all-important covenant.

After this Wright detects what we might call an Exodus complex. God rescues the people of Israel from their oppression in Egypt, dwells with them in the tabernacle and provides instructions through the Torah gifted to them on Sinai. After all this they begin their long journey to the promised inheritance of land, having had a brief but deadly dalliance with idolatry in the golden calf. Once in the land, Wright detects the arrival of kingship and of the cult in the Jerusalem temple. However, all does not go well: Israel fails to be faithful either to God or to its calling to be the salvation of the rest of the world and is punished with devastation, foreign rule and exile conditions that Wright sees continuing to Paul's day.

In short then, an extended, multi-phase plight runs from Wisdom, through creation, the garden of Eden, the covenant with Abraham (comprising promise, and election in Wright's distinctive sense), the exodus, the temple, the monarchy, and, of course, the exile, right down to Paul's context of late Second Temple Judaism. The solution then pivots around the coming of Jesus, the Messiah (who is also God returning to Zion) - a consummate act of divine faithfulness to the original covenant with Abraham, the importance of which for Wright is indicated by the title of his project.

As the Messiah, or Israel's king, Jesus, in the key participatory moment, shoulders the sins of the rest of Israel, which has itself already had the sins of humanity 'heaped' on it after failing to address them. ${ }^{14}$ His death on the cross atones for these in an act of distinctive faithfulness or obedience, and this event justifies all those who respond to it with faith, removing the justified from exile and from the wrath of God in general, at which point an 'eschatological', and somewhat different Israel begins to form.

${ }^{14}$ Wright actually uses this unfortunate expression in his essay 'Romans and the Theology of Paul', in David M. Hay and E. Elizabeth Johnson (eds), Pauline Theology, vol. 3, Romans (Minneapolis: Fortress, 1995), pp. 30-67, on p. 53 (point 6a explicating Rom 7:1$8: 11$ ). He makes a similar claim in Climax, p. 261, where he speaks of Israel's 'meta-sin'. 
This people passes through the new exodus that is baptism and emerges wearing only the badge of faith. Beyond this they are shorn of 'the symbolic praxis of Judaism'15 - something that apparently drives them to theology (see p. 729). But they possess the hearts long promised in the scriptures that are circumcised by the Spirit, ${ }^{16}$ and these enable them to undertake what is basically a virtue ethic, ${ }^{17}$ while they wait for their bodily resurrection, presaged in Jesus'. ${ }^{18}$

This then is basically the story that Wright sees animating Paul's most important thinking. Moreover, he contends that it resolves many of the tensions apparent between other, rival schools of Pauline interpretation. Ostensibly different notions like, for example, participation, justification and theosis are in fact mere moments within a larger story that moves through them, holding them all together within a broader narrative arc. So participation denotes Christ's representative activity on Israel's behalf as Israel's king; justification denotes the verdict of acquittal realised for Christians by the atonement; and theosis denotes the ensuing devotion of the

${ }^{15}$ See pp. 729-30 ('without the symbolic praxis . . . of Judaism'; 'no symbolic praxis except that which was generated from within the gospel itself'). See also p. 401 ('departing'), p. 444 ('done its God-ordained job', 'transcended'), and p. 445 ('redefined', 'left behind' (!), and 'irrelevant').

16 See pp. 923, 1008, 1173, 1379-80. Wright draws repeatedly in this relation on certain OT texts he views as critical for Paul: Deut 10:16 and - supremely - 30:6; Jer 4:4; and see also the uncircumcised hearts mentioned in Lev 26:41; Jer 9:25-6; and Ezek $44: 7,9$. He also connects these texts to important new covenant texts that speak of new hearts and/or of God's instruction being written on the heart: see Jer 31:33; Ezek 36:26-7. These texts all point to the fulfilment articulated in Rom 2:25-9, which is also an important text for his reconstruction. The eschatological Israel, comprised of believing pagans and believing Jews, does not circumcise male converts or observe any embodied provision of Torah (i.e. food laws and the calendar). I analyse this material in Paul in The Deliverance of God, ch. 14, pp. 559-71. Nestle-Aland suggests Paul quotes Deut 27:26/28:58/30:10 in Gal 3:10; Lev 18:5 in v. 12; and Deut 21:23 in v. 13.

17 See pp. 1115-16, 1373-4, 1403-4.

18 Jesus' resurrection attests decisively to his Messiahship, an event that splits the anticipated resurrection of the faithful in two. Those loyal to Jesus must still wait for their concrete, embodied resurrection in the future when, at some unexpected moment, God will return to bring about a new heaven and earth and thereby finally heal the fractures evident since the sins of Adam and Eve - a point where it becomes apparent that Wright does think, at least here, in fundamentally infralapsarian terms. See Edwin Chr. Van Driel, 'Climax of the Covenant vs Apocalyptic Invasion: A Theological Analysis of a Contemporary Debate in Pauline Exegesis', International Journal of Systematic Theology 17 (2015), pp. 6-25. 
ecclesial Israel to virtue. Clearly one of these emphases does not need to be played off against another. ${ }^{19}$

Now this is a distinctive account of Paul's thinking, and even Wright himself would admit that it does not exactly jump off most pages of the Pauline corpus. Hence undergirding it is a set of three methodological moves that enables Wright to tease his story out of enough Pauline texts to facilitate the claim that this is the corpus's key underlying dimension: (1) worldview analysis; (2) 'intertextual maximalism'; and (3) 'Romanocentrism'.

With respect to (1), Wright constantly introduces the worldview of late Second Temple Judaism into his analysis of Paul, utilising a classic sociological text by Berger and Luckman. ${ }^{20}$ And the presence of this interpretative dimension allows the critical claim that, although Paul's worldview might seldom be explicit, it can nevertheless still be ubiquitous, like the lenses on the glasses of a myopic scholar, which are seldom directly seen themselves yet enable all the pages on the desk to be read.

With respect to (2), the intertextual dimension in Wright's analysis is clearly central, but comprises several modes that need to be distinguished. First, it is maximal. Wright sees intertextuality in play everywhere - assisted by the worldview analysis that I just noted. A mere verbal gesture evokes the entire system and so allows the legitimate introduction of that system into Paul's thinking. Paul's intertextuality is also Jewish. He engages with GrecoRoman texts and culture but is shaped by the Jewish scriptures. Moreover, those scriptures are to be read in an integrated, narrative and referential fashion. They tell one principal story that accurately reflects external reality. Hence they recount, we might say, the history of God's relationship with history from creation, through the history of Israel, to the history of the church - an approach, one is tempted to say, that sits comfortably with post-Renaissance expectations of textual construal. ${ }^{21}$

19 All are mere moments that enrich the story without comprehending it; for that one needs the entire narrative - which is, nevertheless, most aptly summarised as 'covenantal'.

20 Peter L. Berger and Thomas Luckman, The Social Construction of Reality: A Treatise in the Sociology of Knowledge (Garden City, NY: Anchor, 1966). As a result, Wright frequently organises his data in terms of symbols, praxis, stories and questions. This is apparent in his first major publication, The New Testament and the People of God, which signalled most of his future interpretative intensions quite clearly. This basic posture also enables Wright to drive a methodological connection through to critical realism, which takes the presuppositions of the observer into account without losing touch with the fundamentally empirical capacity of 'external' data to alter its interpretation.

${ }^{21}$ See here Dale Martin, Pedagogy of the Bible: An Analysis and Proposal (Louisville, KY: Westminster John Knox, 2008). Also helpful at this moment are the classic analyses of 
Finally, with respect to (3), it is of course in Paul's letter to the Romans that Wright primarily detects this extended Jewish history. ${ }^{22}$ The biblical story I summarised earlier that stretches from pre-existent Wisdom, through Adam, Abraham and the tangled history of Israel, to the coming of the Messiah and the eschatological Israel, is detected by Wright in every major sub-section of Romans. So, for example, he claims at one point:

Romans 6-8 constitutes (among other things) a massive retelling of the Exodus narrative. It takes us on the journey through the water by which the slaves are set free (chapter 6), up to the mountain where the Torah is given, with its attendant paradox in that it simultaneously (a) invites Israel to keep it and so find life and (b) confronts Israel with the fact of indwelling sin (chapter 7), and then on the homeward march to the 'inheritance,' again with sombre warnings about not wanting to go back to Egypt [i.e. chapter 8 ]. ${ }^{23}$

Once it has been established in Romans, Wright can detect this story more frequently elsewhere in Paul than would otherwise be the case. ${ }^{24}$

This then is the methodological system that Wright uses to detect Paul's central narrative - an integrated deployment of worldview analysis,

H.-G. Gadamer, Truth and Method, trans. Joel Weinsheimer and Donald G. Marshall, 2nd rev. edn (London: Sheed \& Ward, 1989 [1975]); and David H. Kelsey, Proving Doctrine: The Uses of Scripture in Modern Theology (Harrisburg, PA: Trinity Press International, 1999 [1975]). From Gadamer's point of view, Wright's reading of (Paul's reading of) Jewish scripture would be largely 'reproductive' not 'productive'.

22 The main moves in his distinctive reading are already apparent in his doctoral dissertation, submitted at Oxford in 1980. Essays on smaller component parts of the reading have appeared in various places since then. But its most comprehensive account is the 400-page exposition, 'The Letter to the Romans', that appeared in 2002.

${ }^{23}$ FSG, p. 659; see also p. 703: 'Paul has told the great story of Israel, from Abraham to the Messiah (9.6-10.4), arguing that in the Christos, however paradoxically, God's single purpose and promise from the beginning has found its telos, its goal'; and p. 822: 'a very strong prima facie case can be made for seeing Paul's intention [in 9.6-10.13] as being to present a narrative outline of the history of Israel from Abraham to the present time, working through the other patriarchs to Moses and then to the prophets, the exile and ... the Messiah [in 10:4]'. Cf. p. 422.

24 Although, having said this, he does not necessarily need to. If Paul's worldview is most plainly apparent in Romans, then it simply follows that Romans is the clearest window onto that worldview and the most important text for reconstructing his thinking. Doubtless Paul had his reasons for being less explicit on many other occasions. 
intertextual maximalism and Romanocentrism. ${ }^{25}$ It is time to ask what we should make of it. $^{26}$

I actually had an 'aha' moment when I was reading through PFG, when all the disparate pieces swirling around suddenly clicked into place and I felt that a window had opened up onto Wright's worldview. There is a sense in which Wright's account of Paul's soteriology in terms of a sweeping biblical story is, underneath it all, simply the Lutheran reading writ large. This might seem a surprising claim at first blush so let me try to explain what I mean by it.

The Lutheran reading is a simple but powerful account of the Pauline gospel that moves from a plight established by failed law-observance to a solution made possible by Christ's satisfactory atoning death and grasped by faith. ${ }^{27}$ Hence it moves from Judaism to Christianity (as well as, in some versions, from Catholicism to Protestantism), from a phase characterised

25 A slightly more extended summary: the text of Romans is probed in terms of its Jewish intertextuality. And components from the Jewish worldview are introduced to make sense of this lurking intertextuality, which is threaded together in stable, essentially historical terms. The result is that the text of Romans is held to articulate an integrated, Jewish, story of God and history that flows from creation, through an Abrahamic, Mosaic and then exilic plight, to a climactic Messianic solution. (It is of course a little worrying that this reading of Romans is generated by appealing frequently to its underlying worldview, since this reading seems to underlie the account of this worldview so much elsewhere!)

${ }^{26}$ I suspect that it is this distinctive methodological approach that makes Wright so difficult to process in scholarly terms. Although he can read the details of a text very carefully and explicitly if he wants to - see his engagements with Gal 6:16 (pp. 114251) and Rom 11:26 (pp. 1231-52) - such moments are rare. Usually, Wright simply asserts that various echoes are operative for a particular passage, although these are sometimes mobilised and/or bound together simply by his account of Paul's Jewish worldview, and, at others, by the fact that they appear in the same biblical book. Moreover, he detects echoes from all points of his narrative compass - from creation, the patriarchs, the exodus, the cult, kingship, exile, and judgment, sometimes adding Greco-Roman resonances for good measure. (His treatment of Phil 2:5-11 is a nice example of this distinctive, heavily layered approach; see pp. 680-9, 1293-5.) One has to concede the worldview for this argument even to make sense. And one still has to consider whether the individual echoes are operative or merely possible in relation to the detailed data of the text, hopefully cocking one eye towards the text's contingency, which Wright generally underplays. Wright is easy to read, frequently supplying witty quips and turns of phrase as only he can, but he is hard to analyse and to assess.

27 As noted earlier, this nomenclature goes back to Stendahl's classic analyses (see esp. 'The Apostle Paul and the Introspective Conscience of the West', but also his Paul among Jews and Gentiles, and Other Essays (Philadelphia: Fortress, 1976)). I call it 'the justification discourse' or 'JF reading', and describe its actual soteriological commitments and moves in detail in The Deliverance of God (see n. 37 below). These commitments and 
by law to a very different, somewhat denuded phase characterised by faith alone. Hence it imposes a harsh binary opposition on the Bible that Wright suspects (probably correctly) of facilitating Marcionism. ${ }^{28}$ Furthermore, it is a highly individualised account and consequently somewhat atemporal and ahistorical. Scholars frequently denote this with the word 'anthropological', but really mean 'anthropocentric': salvation is the journey of a single person, oriented by her thinking throughout. ${ }^{29}$

We could, however, conceivably address these difficulties if we simply historicised this story more comprehensively - if we spread its phases out through time and space. We could then take in the full sweep of the Bible (reading it in a certain sense, of course). The plight would stretch from Genesis 3 to Malachi, with the solution arising out of this extended Jewish story. We could go on to speak of peoples and histories (as against speaking of individuals and introspection), and we could even introduce the occasional sociological flourish. ${ }^{30}$ Moreover, the Marcionite danger would seem to be well and truly repulsed as a more complex and palatable story binds the plight articulated by the Old Testament tightly into its Christian resolution. ${ }^{31}$ But the underlying plotline here would still be fundamentally Lutheran, moving from a plight under the law to a solution in Christ effected by way of a penal substitutionary atonement that is grasped by faith alone.

I would suggest that this is basically what Wright does for much of the time, such that his principal, soteriological agenda in PFG is, at bottom, underneath it all, what we could call 'panoramic Lutheranism'. ${ }^{32}$ The key challenge for him in this strategy is, of course, finding this broadened,

moves are also nicely articulated in Piper, The Future of Justification: A Response to N. T. Wright (Wheaton, IL: Crossway Books, 2007).

28 That is, I think he is right about this. If Judaism is a nasty, legalistic calculus then some scholars will be strongly motivated to detach Paul's gospel from it altogether, rooting it in some nobler, alternative cultural background like ancient Greek heroic traditions, Roman saviour figures or some such.

29 The compatibility of this model with much modern European thinking hardly needs to be pointed out, although this compatibility is also not coincidental; 'modern European thinking' developed from largely Protestant academies.

30 As is well known, Wright gives an account of 'works of Law' in Paul - at least at times - in terms of 'sociological boundary markers'. This supplies in his view a more satisfactory account of Paul's difficulties with Kephas in Syrian Antioch (Gal 2:11-14), amongst other things.

31 At least putatively; there are arguably some difficulties lurking here.

32 This is, incidentally, why Wright dislikes being called salvation-historical, if by the latter is meant an essentially evolutionary, progressive, historical account; his narrative preserves some of the harshness of the classic Lutheran binary so he is right to protest here in these terms. 
corporate narrative in Paul, since the all-important opening texts in Romans have usually been understood to speak of individual justification. But we have already seen how Wright makes his case, rereading Romans 1-4 (along with 5-8) in terms that devolve into the more panoramic discussions of Romans 9-11, although reading those later discussions consistently in terms of the fundamental plight-to-solution argument of the earlier chapters. One important result from this strategy is a highly hermeneutical Paul. He is now above all a reader of Jewish scripture, although one that reads in a particular way. ${ }^{33}$

This realisation explains quite a lot about Wright's reception, and subsequent position on the broader scholarly chessboard.

Those with biblicist proclivities find much to like here. This Paul remains recognisable for those journeying away from what we could call classic Lutheranism. Wright's Paul is more satisfyingly canonical than the old model, not to mention more historical in approach, although he remains reassuringly stable in hermeneutical terms. ${ }^{34}$ And this is all potentially much fresher homiletically than the somewhat tired and strident Lutheran assertions. ${ }^{35}$

But outside of this constituency, Wright has caused offence. The classic Lutherans are of course offended by Wright's abandonment of classic Lutheran soteriology. They complain that he is unclear at critical points about key questions. ${ }^{36}$ And they are unconvinced by his detailed exegesis,

33 And hence Wright's preoccupations with Francis Watson's Paul and the Hermeneutics of Faith (London: T\&T Clark International (Continuum), 2004). Watson argues carefully and extensively for an account of Paul as a reader of Jewish scripture, who nevertheless differs significantly from Wright's reconstruction, and operates against a rather different account of his Jewish background. Wright engages this account on pp. 1456-71, but his response essentially amounts to a restatement of his own position.

34 Moreover, Wright's appeal to history can also function apologetically. Good history and good exegesis deliver key Christian truths in a way that is incontestable, or at least provable, in the public domain. Wright exudes Christian confidence, and especially in the Bible. Furthermore, he explicitly attacks Marcionism and Gnosticism, in both its ancient and modern variations: the prior importance of the creator God is everywhere maintained.

35 Different elements within the scriptures can be woven together from the pulpit in a way that is far richer and more engaging than preaching rooted in the bald antithesis of the Lutheran individual journeying from guilt to faith. The homiletic dimension to Wright is important.

${ }^{36}$ For example, concerning the basis of assurance during the last judgment, and the role of works (Piper's main concerns in his The Future of Justification). Classic Lutherans are not sure how all Wright's proposals fit together. Certainly his account of justification, for example, cannot be explained easily in a little tract like 'The Four Spiritual Laws'. (See Wright's engaging but complicated Justification: God's Plan and Paul's Vision.) 
especially of Paul's justification texts. Romans 1-4 just does not say explicitly what Wright says that it does, in their view. ${ }^{37}$

And what of the agendas of the academy? It is important to appreciate that I am not suggesting that PFG is entirely reducible to panoramic Lutheranism, even if it is, in my view, dominated by it. Wright also affirms Paul's engagement with the imperial cult, and with surrounding popular piety (i.e. religio) and philosophy. ${ }^{38} \mathrm{He}$ doubles down on the recent divine identity debate (as I will note in more detail momentarily). And he strongly emphasises bodily resurrection, to oppose an ostensibly gnostic Paul. Peeping through the cracks of many of these concerns is a connection with his work

37 I agree with some of their complaints in this relation. For more detail, see my Deliverance of God, esp. chs. 14-21; these chapters supply my detailed suggested exegesis of all Paul's justification texts. I address 'new perspective' readings esp. in ch. 12. Exegetical problems with classic Lutheranism are adduced in chs. 2-6 and 11. The implicit theoretical or theological account of salvation is articulated in ch. 1, and its exegetical basis articulated in ch. 10. The broader, complex interpretative situation is theorised in ch. 7 and expanded in chs. 8 and 9. I address exegetical questions in Romans 5-8 in a little more detail in 'Christ and the Church in Paul: A "Post-New Perspective" Account', in Michael Bird (ed.), Four Views on the Apostle Paul (Grand Rapids, MI: Zondervan, 2012), pp. 113-43. This essay presages a detailed reading of Romans on which I am currently working, tentatively titled The End of Religion: An Augustinian Reading of Romans (Grand Rapids, MI: Eerdmans, forthcoming).

38 Wright emphasised this aspect of his project recently in his lecture, "Why and How Paul Invented "Christian Theology”' (11 Nov. 2014; Duke Divinity School). Given space and time, I would very much like to engage with this claim more deeply. It must suffice to say that he emphasises a certain symmetry between Paul's thought and the basic philosophical categories of the day - '[meta]physics', 'ethics', and 'logic' emphasising also their interrelationships. His initial claim seems to be that as such Paul would have been intelligible to pagan philosophers. This claim was accompanied by criticism of the early Barth, who was supposedly (to paraphrase his text) 'speaking from inside the Christian house and hence had nothing to say to those who were standing outside the front door'. I take it that Wright means by this that Barth's theology, at least in his Römerbrief, provides no 'point-of-contact' (Anknüpfungspunkt) for non-Christians, the underlying and most important assumption here being that Christians ought to provide such a connection in fundamentally intelligible, rational terms, something that presupposes in turn a demonstrable common rationality. This would allow the nonChristian to approach the front door - and indeed might even compel them, if they are rational, to do so. Wright's citation of Acts 17 seems to confirm this interpretation of his claims. Much could be said to this by way of response, and indeed critique. It is, in the first instance, a deeply naïve view of conversion. Deliverance of God articulates this insight in ch. 5. An accessible and compressed version of the same concern can be found in Rodney Stark, 'Conversion and Christian Growth', ch. 1 of The Rise of Christianity: A Sociologist Considers History (Princeton: Princeton University Press, 1996), pp. 3-27. 
on the historical Jesus, so the 'Jesus and Paul' debate is also in view. But a lot of modern scholarly concerns are still missing from this account.

Paul's contextual engagements are generally characterised conceptually by Wright as a clash of worldviews. ${ }^{39}$ But Paul's utilisation of Greco-Roman culture was arguably a more subtle, complex and multi-directional process than this sort of characterisation would suggest. ${ }^{40}$ Similarly, the sociological analysis of Paul's communities in PFG strikes me as just a tad reductionist and haphazard. ${ }^{41}$ We do not learn about how they were established, or about how their key dynamics fitted coherently together (i.e. other than hermeneutically). ${ }^{42}$ Indeed, it is significant that we gain very little sense from all this of Paul the missionary (which is primarily what he was). He tends to disappear behind Paul the Bible reader.

Wright has little interest in contingency - a major methodological concern of North American scholars since the work of Beker in the 1980s. ${ }^{43} \mathrm{He}$

39 See esp. chs. 12-14.

40 The motifs of benefaction and reconciliation - and, I would add, of redemption are central categories for Paul's gospel, yet they seem to have been drawn from his Greco-Roman context. We would have to discuss Paul's use of 'adoption' as well. And he is clearly comfortable with talk of Christ's parousia, an explicitly imperial motif.

41 The account of Corinth addresses the community's rites and practices, but devolves fairly quickly into a hermeneutical account of baptism as a new exodus (see pp. 41722). Sacrifice, prayer, worship and discernment are then discussed - all important aspects of the community, to be sure. But little account is taken of contextual engagements with street religion or 'magic', or with possible conversions from the Mysteries. Moreover, one could wish for a deeper, stronger account of the eating and meal practices; money and economics; miracles; the new treatment of time; and the rite of burial. (Baptism also possibly had some relation to 'the dead'.) The Gospel's transformation of shame could be explored more. And Paul's complex engagements with various aspects of sexual ethics could be usefully explored, since they place pressure on a simple binary account of gender and sexual behaviour in various respects. Moreover, underlying all these complex dynamics is the question whether a simpler, more powerful explanation can account for them coherently. I appreciate then that Meeks' agenda is firmly in play, but I think more needs to be done.

42 Paul comes across as the ancient equivalent of someone standing on a soap box at the corner of Hyde Park proclaiming his new worldview and expecting that this will get things going. But we do not know that he did this very much, and there are good reasons for thinking that this was not his most effective mode of evangelism in any case (see 1 Thess 2:9). Modern literature on conversion would bear this out, as just noted in n. 38 .

${ }^{43}$ It pops up from time to time when a supportive argument is useful, but contingent claims are not grounded in any articulated and justified biography, while, somewhat strangely, the possibility of achieving such a biography is largely denied: 'we do not know the exact order in which Paul wrote his letters', although we suspect that 1 Thessalonians is early, Romans late, and 1 Corinthians written before 2 Corinthians. 
makes scant use of Paul's biography, overlooking certain moments when it problematises his reading. ${ }^{44}$ Post-modernism is dismissed. ${ }^{45}$ Alternative accounts of intertextuality are not really dealt with. ${ }^{46}$ The apocalyptic reading of Paul is generally rebuffed, if not mischaracterised. ${ }^{47}$ Participation is

'But beyond that it is hard to proceed' (p. xix). See also pp. xx and 56-63. Curiously, Wright's assertions regarding authorship - and his minimal claims above concerning order - are, at least in my view, largely on the money, along with much of his reasoning, although rather more needs to be done to complete the rehabilitation of Ephesians, Colossians and 2 Thessalonians. And these texts need to be folded into an order and a biography, along with Galatians, Philippians and Philemon (see my Framing Paul). J.-Chr. Beker's classic methodological statement is asserted and developed in Paul the Apostle: The Triumph of God in Life and Thought (Philadelphia: Fortress, 1980).

44 The complete failure of Paul, the Bible reader, to recognise the many aspects of Jesus and the early Christian movement that fulfilled the scriptures he knew so well prior to his call is a major problem. If hermeneutics was the key to his thinking, its central realisations should not have arrived so suddenly and dramatically, through divine intervention, on the road to Damascus - and this is a standard biographical conundrum for interpretations of Paul that emphasise his scriptural learning heavily.

45 A masterful account of the actual methodological concerns of post-modernism is supplied by Alasdair MacIntyre in Three Rival Versions of Moral Enquiry: Encyclopaedia, Genealogy, Tradition (Notre Dame, IN: University of Notre Dame Press, 1990). It is confused to suppose either that post-modernism is fundamentally liberal, or that it lacks a particular articulated method and set of concerns, as Wright often seems to. He is correct, however, to be concerned about the generally muddled deployment of this method and these concerns within NT studies (as arguably often within the Humanities more generally).

46 I mean by this three sorts of accounts in particular: (1) from scholars like Christopher Stanley, in terms of ancient reader competence; (2) from scholars like Donald Juel, in terms of the actual practices of ancient Jewish exegesis; and (3) from scholars like Richard Hays, who see a more christological and retrospective hermeneutic in play, at least at times. This last is an especially important conversation partner because Wright cites him with approval so often. And yet Hays' overtly christological reconstructions of Paul's hermeneutics are at times significantly different from Wright's more historicised readings. A classicist like William A. Johnson would add grist to the mills of (1) and (2), as he painstakingly reconstructs ancient systems of reading, which are dramatically different from modern systems (see his 'Toward a Sociology of Reading in Classical Antiquity', American Journal of Philology 121 (2000), pp. 593-627). We need to be reminded that reconstructing an ancient reading encyclopedia in general, and a reader in particular, is a profoundly cross-cultural exercise.

47 The most egregious instance of this would be Wright's climactic assertion that Martyn is one of the three figures within Pauline interpretation to be most avoided in the future - along with F. C. Baur and R. Bultmann - in part because of the complicity of his type of reading in the rise of National Socialism! 'When the Nazis were constructing a newly integrated form of would-be philosophically grounded community, they found anti-semitism to be an ideological necessity, not merely a pragmatic desideratum. There could not be two chosen peoples. There could not, in particular, be two histories: 
reduced to a clutch of obscure intertextual motifs in the Old Testament, undergirded by the implausible notion of corporate personality. ${ }^{48}$ And the massive recent concern of scholars, both within Pauline studies and within the modern university more generally, with alterity, is rebuffed. So Wright largely overlooks the question voiced clearly at least since Sanders in 1977 that certain readings of Paul construct Judaism in a sinister fashion and yet depend on that construction for their own validity. ${ }^{49}$ Hence it seems significant that Torahobservant, Jewish Christianity is simply missing from Wright's account: his reading erases it, and his fundamentally Lutheran plotline is revealing itself in much of this. ${ }^{50}$

We could summarise this by saying that Horsley, Bauckham and Hurtado are in play, along with a certain account of Hays (i.e. one he might not be entirely happy with), but the development of Meeks is thin. And the work of Baur, Sanders, Beker, Stanley, Juel, J. L. Martyn, D. Martin, Engberg-Pedersen,

the Jewish history had to be erased, by the burning of the Torah as well as by the killing of its devotees, in order that the fresh Nazi story of Germany could stand on its own new feet' (pp. 1476-7). Wright then comments in a footnote (n. 8, p. 1477): "The parallel between this and the proposals of today's neo-"apocalyptic" interpreters of Paul is, or should be, a matter of concern.' The fonts of this tradition are shortly named as Martyn and Käsemann, but it runs to 'three generations', and from elsewhere in PFG one gathers that its adherents include Keck, de Boer, Gaventa, Harink, Brown, Eastman and Campbell. Certainly I would add Rutledge and Cousar immediately to Wright's list, and interesting questions would have to be asked about Gorman, Grieb, Barclay, Watson and Hays. Be that as it may, it is ironic that Wright levels this (genocidal!) charge against the apocalyptic school when of course they level a charge of supersessionism against him.

${ }^{48}$ See pp. 779, 825-35. It is so significant it merits no entry in the index, but is referred to by “"incorporation” into Messiah'. See 2 Sam 19:43 (LXX); 20:1; 1 Kgs 12:16.

${ }^{49}$ He does not of course overlook Sanders, but - at least arguably - he states the concerns and programme of Sanders in such a way that this particular question is bypassed. Indeed, Sanders almost inverts into his opposite, turning out to encourage the reading of Judaism in a legalistic 'religious' way (p. 1323)! I see rather different claims and issues in play in Paul and Palestinian Judaism (Philadelphia: Fortress, 1977); see The Deliverance of God, ch. 4.

50 Wright's antipathy to F. C. Baur probably has led to his overlooking of this critical contribution to Pauline studies. See, more recently, Annette Yoshiko Reed, “'Jewish Christianity" after the "Parting of the Ways": Approaches to Historiography and SelfDefinition in the Pseudo-Clementines', in Adam H. Becker and Annette Yoshiko Reed (eds), The Ways that Never Parted: Jews and Christians in Late Antiquity and the Early Middle Ages (Tübingen: J. C. B. Mohr (Paul Siebeck), 2003), pp. 188-231; and “"Jewish Christianity" as Counter-History? The Apostolic Past in Eusebius' Ecclesiastical History and the Pseudo-Clementine Homilies', in Gregg Gardner and Kevin L. Osterloh (eds), Antiquity in Antiquity: Jewish and Christian Pasts in the Greco-Roman World (Tübingen: J. C. B. Mohr (Paul Siebeck), 2008), pp. 173-216. 
Gaventa, Gorman, Watson and Barclay is rebuffed. It goes without saying that Bousset, Bultmann and Stendahl are off the table, along with, perhaps most surprising of all, Ernst Käsemann. ${ }^{51}$

One is tempted to observe at this point that Wright has cut himself off from almost every other major interpretative approach in modern Pauline studies, which is to say, that Wright himself must view the bulk of modern scholarly work on Paul, especially in North America, as an aberration. But the underlying reason why this spread of occlusions has happened is now becoming clear: the advocacy of a fundamental description of Paul as a reader of scripture, who reads, moreover, in a fundamentally Lutheran way - although in a manner that offends classic Lutherans. This is a big problem.

If Paul is primarily a Jewish Bible reader telling a Messianic story that builds from a massive Jewish plight to the Gospel's solution, then it is hard to see how the main problems of Lutheranism have been avoided rather than simply recast in a corporate mode. The people of Israel still fail self-evidently to fulfil their assigned task, and the law still proves to be self-evidently inadequate. Hence the fundamental othering of the Jew is still apparent, although here within the historical journey of an entire people; and this alienation is still the basis for a Christian solution that erases the symbolic praxis of that people - somewhat opaquely, I would add. ${ }^{52}$ And it remains puzzling why God would relate to Israel in terms of a plan A, the law, which is designed to fail, moving only later to his personal involvement through a different plan $\mathrm{B}$ - all the while continuing to hold Jews, along with the rest of humanity, accountable to the impossibly harsh requirements of plan A. This God is unrecognisable to most Jews, ${ }^{53}$ while Christ's involvement

51 "The entire enterprise of contemporary "apocalyptic" readings of Paul got off on the wrong foot, in fact, when Käsemann picked up from the climate of the times (a further irony) the notion that perhaps "apocalyptic" meant a totally new revelation which would take up all the hermeneutical space available, leaving no room for anything that went before' (p. 1481). 'In doing so he [Käsemann] tacitly admitted . . . that his "apocalyptic" was actually not so very different from the "Gnosticism" it had displaced in his reconfiguration of Bultmann's theory of Christian origins' (p. 1482). Käsemann, I imagine, would have been surprised to hear this.

52 That it does so is strictly speaking a non sequitur, but now is not the place to develop this realisation.

53 Sanders argued that no sources contemporary to Paul articulated this harsh view, with the possible exception of 4 Ezra. I am not quite as confident as he is about this, partly because of 4 Ezra and the opinions of the angel Uriel there, but also in view of Wisdom and a few related texts like Ps Sol 2, 4, 6, 8, 9, 10, and 15, along with the general propensity of humanity to erect contractual and conditional arrangements with God. See James B. Torrance, 'Covenant or Contract: A Study of the Theological Background of Worship in Seventeenth-Century Scotland', Scottish Journal of Theology 23 (1970), pp. 51-76. 
in salvation in these terms is secondary, and only partially successful (!). So some of Lutheranism's key problems are still present and, given time, I could add many more. ${ }^{54}$

Moreover, it is very difficult to extend this analysis of Paul in fundamentally hermeneutical terms into the other scholarly areas just mentioned. The picture of Paul as fundamentally a professor of scripture, reading in a certain delineated way, does not unpack smoothly or obviously into missionary work, community formation, network evangelism, semantic contextualisation, participation, apocalyptic construed as revelation, polysemous intertextuality, dissonant worldview analysis (i.e. in post-modern terms), or sensitivity to the other. And he will not even necessarily unpack into good Christian theology, as the posture of many Bible scholars in the South before the Civil War - to pluck just one example from church history - makes abundantly clear. ${ }^{55}$ So it is becoming increasingly apparent that this basic strategy might have painted Wright into a corner. His recast Lutheran plotline has failed to solve most of its old problems, while his fundamentally biblicist portrait has ended up rather isolated, with few places to go in terms of the broader scholarly agenda.

However, let me be quite clear: it is important to resist Marcionism along with adoptionism and gnosticism - within Pauline interpretation. I fully share Wright's concerns here. And it is quite acceptable to argue for a hermeneutical dimension within Paul's description; indeed, it is essential. But the acceptance of a fundamentally Lutheran plotline in this hermeneutic is a major mistake; Paul's plotline is christological! And the reification of hermeneutics into the basis of Paul's entire description is a mistake as well. It seems that, if we make this move, we start Paul's description in the wrong place. Indeed, this is arguably just a classic instance of 'methodological foundationalism'. ${ }^{56}$

54 The Deliverance of God enumerates these much more fully - although admittedly somewhat overzealously; see e.g. pp. 215, 593-9.

55 See Willard M. Swartley, Slavery, Sabbath, War, and Women: Case Issues in Biblical Interpretation (Scottdale, PA: Herald Press, 1983), esp. pp. 31-64; and also Wayne A. Meeks, 'The Polyphonic Ethics of the Apostle Paul', Annual of the Society of Christian Ethics (1988), pp. 17-29; Meeks , 'The "Haustafeln" and American Slavery: A Hermeneutical Challenge', in Eugene H. Lovering Jr. and Jerry L. Sumney (eds), Theology and Ethics in Paul and his Interpreters: Essays in Honor of Victor Paul Furnish (Nashville, TN: Abingdon, 1996), pp. 245-52; and J. Albert Harrill, "The Use of the New Testament in the American Slave Controversy: A Case History in the Hermeneutical Tension between Biblical Criticism and Christian Moral Debate', Religion and American Culture 10/2 (2000), pp. 149-86.

56 An earlier brief account of these self-defeating dynamics, along with a description of a healthier way to proceed vis-à-vis salvation history, is my essay, 'Paul 's Gospel, 
In PFG a particular concern or anxiety has led to the foregrounding of a particular response - up front. The need to deal with this concern is so great that the (putative) corresponding solution has been inserted into the very foundation of all further analysis. So Wright's anxiety (for example) about Marcion's sundering of the testaments has led to the insertion of Paul's biblical work into the heart of his analysis; it is the basis for everything else. This commitment is supposed to guarantee the practice's success and permanence. However, the result of this decision is arguably the opposite of these worthy goals, and for two principal reasons.

First, this foundation must now be laid and defended up front precisely as a foundation - i.e. established 'objectively' - which is always difficult if not impossible. A massive a priori descriptive task has been assumed and the likelihood of success looks slim, as it requires Wright basically to be right about everything in the OT and its ancient Jewish interpretation.

And, secondly, this particular foundation - which is a certain set of concerns and a point of view for their solution - must now occlude all subsequent agendas and data that it cannot explain or incorporate, because if it does not do this, then its own role as a foundation will be called into question. An explanatory foundation that cannot comprehend or explain key pieces of the data is clearly not in fact a valid foundation. So unexplained data are deeply threatening to foundationalism, leading to the reduction of data to the concerns and perspective already in place.

In short, in methodological foundationalism, anxiety begets a putative solution in the form of a foundational commitment to that solution. And this begets, in turn, a massive and fragile initial descriptive task, followed by a characteristic reduction of everything to that agenda, at which point the entire project begins to crumble, and this response to the initial concern turns out to be self-defeating. And this is where I suspect that we have ended up in PFG. Wright actually develops his foundationalism in a revised Lutheran format. But it still thereby retains all the difficulties of foundationalism, along with the particularly nasty difficulties Lutheran foundationalism activates to boot.

Now Wright would probably respond that we have to start somewhere, and I agree. But we need to start in the right place - at a point in Paul from which all his other activities and concerns can ideally be comprehended and explained constructively. And I think we know where this is. Indeed, I think Wright does as well. It is time to introduce - very briefly - the second main interpretative agenda in $\mathrm{PFG}$.

\footnotetext{
"Apocalyptic", and Salvation-History', in The Quest for Paul's Gospel: A Suggested Strategy (London: T\&T Clark International (Continuum), 2005), pp. 56-68, esp. 63-5.
} 


\section{The anti-adoptionist agenda}

In chapter 9 of PFG Wright argues that Paul 'freshly reworks' conceptualities drawn from late Second Temple Judaism to articulate Jesus' inclusion within the divine identity. ${ }^{57}$ That is, Wright is well aware that these conceptualities do not lead directly to the key Christian claim that Jesus, a low-status Jew from Nazareth, is divine - the recognition that later theologians articulated more precisely in terms of the incarnation and the hypostatic union. The Jewish conceptualities allow the articulation of this claim but do not generate it, while their original scriptural authors might have been somewhat surprised by it. Indeed, this claim is unexpected, even shattering, and especially when it is recalled that Jesus, resurrected and enthroned as Messiah and Lord, was first executed. An executed Messiah and a crucified God?! This is new from a human point of view. ${ }^{58}$ Consequently Wright himself refers to the arrival of the realisation concerning the cross of Christ as 'a flash, at a trumpet crash... as though a sudden bolt of lightning, right outside the window, shone a beacon into a previously dark room' (p. 407), and to the cross itself as 'a strange, outlandish event, in which the one God did something completely new, utterly drastic, world-changing, world-shaking, [and] world-remaking' (p. 408).

So Wright is well aware that a moment of revelation has taken place, in the light of which some of the conceptualities of late Second Temple Judaism have been 'freshly reworked', and in certain respects, dramatically so. It has been revealed to Paul and the early Christians that the executed and resurrected Jesus is the Lord, something from which much will now follow. This was the revelation that stopped Paul in his tracks on the road to Damascus, turning him from a fundamentalist persecutor into the champion of the pagan mission. But it follows directly from this that the nature of God must now be understood with primary reference to the figure of Jesus, from which it follows further that the purposes of God, in creation, redemption and the eschaton, ought to be understood with primary reference to the figure of Jesus as well..$^{59}$ It is, in short, apparent in Wright's endorsement of Paul's

57 Characteristically, he adds a hermeneutical dynamic to the work of Bauckham and Hurtado, arguing, somewhat problematically, for Paul's recognition of Jesus as God returning, as promised, to a vacant temple and to Zion.

${ }^{58}$ Hence - in a telling moment - Wright even cites with qualified approval J. L. Martyn's important 1967 essay on theological epistemology, 'Epistemology at the Turn of the Ages' (p. 1356), now available in Martyn, Theological Issues in the Letters of Paul (Nashville, TN: Abingdon, 1997), pp. 89-110.

59 Given time, I would want to explore the particular categories that Wright sees Paul using at a basal level here. Wright equates 'Christ' constantly with 'Messiah', hence tends to move in a fundamentally ethnic and political direction. However, Paul's 
christological monotheism that the correct starting point for the analysis of Paul is - to appeal to the Greek root instead of to the Latin - apocalyptic. ${ }^{60}$

So I would suggest that Wright already knows the answer to the question posed by his struggling hermeneutical programme, because he endorses it vigorously himself in his second principal analytic agenda concerning monotheism and eschatology - that is, his agenda concerning God. The analysis of Paul's thought must begin with the revelation that the fullness of divinity dwelled bodily in Jesus - a starting point that must immediately devolve into a freshly reworked account of creation, history and scriptural interpretation. But where does this realisation leave us in our overarching assessment of the account of Paul's theology offered by PFG?

It is immediately apparent that Wright needs to stop trying to saw off a branch that he is actually sitting on for half of his project, and that he needs to sit on for the other half. A consistently apocalyptic starting point would ground his soteriological and hermeneutical agenda on an unshakeable foundation, and might also buy him some much-needed allies within the academy. Indeed, let us be crystal clear at this moment.

I fully endorse Wright's trenchant repudiation of fundamentally Marcionite, adoptionist and gnostic, elements within Paul's interpretation, whether ancient or modern. These are historically implausible and theologically destructive. And I fully endorse the importance of Jewish conceptualities for Paul's thinking, and the consequent relevance of the apostle's subtle interactions with the Jewish scriptures. But it is quite clear that

critical category was arguably the one that later orthodoxy placed at the centre of its confessions, namely, 'Son', entailing a fundamentally filial and familial account of Christ, and of the situation those transformed in him occupy ('sonship'). On Paul's use of this important language see my essay 'The Narrative Dimension of Paul's Gospel, with Special Reference to Romans and Galatians', in The Quest for Paul's Gospel, pp. 69-94. My key claims here are that the language of 'father', 'son', 'sonship' and 'adoption', is informed by the patriarchal narratives concerning Abraham, Sarah and Isaac, not to overlook Hagar and Ishmael. As such, the filial and familiar categories are significant, although the gendered dimension within the stories is irrelevant. The OT intertexts structure the relations between the different characters in narrative and dramatic terms. God 'the father' offers up Isaac, as Abraham did; God 'the son' obediently is offered up, like Isaac. This suggests that Paul's use of this terminology has critical implications for personhood but detaches those implications from gender.

${ }^{60}$ As noted earlier, Wright's own, polemical account of Paul's apocalyptic interpreters should be ignored. It fails to map their key concerns or implications precisely. They are actually concerned - at least for much of the time - with the concerns he himself also endorses as outlined briefly here. See in addition to Martyn's essay ‘Epistemology at the Turn of the Ages', his famous treatment, 'From Paul to Flannery O'Connor with the Power of Grace', in Theological Issues, pp. 279-97 (first published in 1981). 
these worthy objectives cannot be achieved by reconstructing Paul's thought in terms of an a priori hermeneutical foundationalism. That foundation will occlude key conversations, isolate itself, and ultimately collapse. And it will be especially unhelpful to construct that foundation with a fundamentally Lutheran plotline, that runs from a plight under law to a deracinated Christian solution. It is therefore self-contradictory and self-destructive for Wright to deny the importance of starting Paul's interpretation in apocalyptic terms. Instead, a freshly reworked account of Paul should begin with the revelation of God in Christ and go on to deconstruct and rework any fundamentally Lutheran plotline and its associated reading of scripture - just the agenda of the apocalyptic camp that Wright spends so much time marginalising, that is, when he is not advocating it himself.

In short, the key lesson that arguably emerges from a careful parsing of Wright's account of Paul's theology in PFG is the realisation that a robust, coherent, and dynamic account of the apostle's theology cannot compromise with Lutheranism; to do so is to doom that account to failure, as here, and in numerous ways. Rather, the future of the apostle's theology is - as Wright himself intimates, at times in spite of himself - apocalyptic. But it must be apocalyptic in a resolute manner that moves consistently and courageously beyond Wright's ambivalence, both by committing to that starting point with all its consequences, and by purging the apostle's thinking of alien categories that most often intrude under the guise of a law-gospel sequence that is derived ultimately from a vulgar account of Lutheranism. As Wright himself might say, a proper account of Paul must not be a (bad) twentiethcentury account of a sixteenth-century problem - although neither must it be a twenty-first-century response to some second-century problems; it must in fact be a universal response to a universal problem, albeit one that arrived in all its particularity around about AD 30, and that showed us then exactly what problem it is that has trapped us all. 